\section{Adverse childhood experiences and consumption of alcohol, tobacco and illicit drugs among adolescents of a Brazilian birth cohort}

\author{
Experiências adversas na infância e consumo de \\ álcool, fumo e drogas ilícitas entre adolescentes \\ de uma coorte brasileira
}
Experiencias adversas en la infancia y consumo de alcohol, tabaco y drogas ilícitas entre adolescentes de una cohorte brasileña

Helen Gonçalves 1

Ana Luiza Gonçalves Soares 1

Ana Paula Gomes dos Santos 1

Camila Garcez Ribeiro 1

Isabel Oliveira Bierhals ${ }^{1}$

Luna Strieder Vieira 1

Natália Limões Hellwig 1

Fernando C. Wehrmeister 1

Ana M. B. Menezes ${ }^{1}$

\begin{abstract}
The objective of this study was to investigate the association between adverse childhood experiences (ACEs) and the use of alcohol, tobacco and illicit drugs among adolescents from a Brazilian cohort. The occurrence of five ACEs, the use of alcohol and tobacco and trying illicit drugs were investigated in the 1993 Pelotas birth cohort at the age of $15(n=4,230)$. A score was created for the ACEs and their association with the use of substances was evaluated. Around 25\% of adolescents consumed alcohol, 6\% smoked and $2.1 \%$ reported having used drugs at least once in their lives. The ACEs were associated with the use of alcohol, tobacco and illicit drugs. A dose-response relation between the number of ACEs and the substance use was found, particularly with regard to illicit drugs. The occurrence of ACEs was positively associated with the use of alcohol, tobacco and illicit drugs among adolescents and the risk may be different for men and women. These results point to the fact that strategies for preventing the use of substances should include interventions both among adolescents and within the family environment.
\end{abstract}

Substance-Related Disorders; Smoking; Alcohol Drinking; Street Drugs; Adolescent

\author{
1 Programa de Pós-graduação \\ em Epidemiologia \\ Universidade Federal de \\ Pelotas, Pelotas, Brasil.
}




\section{Introduction}

Experimentation and use of alcohol, tobacco, and illicit drugs typically begin in adolescence and the consumption of these substances is considered a relevant public health issue 1,2. According to the Brazilian National Survey of Student Health (Pesquisa Nacional de Saúde do Escolar - PeNSE), carried out in 2012, 26.1\% and 5.1\% of adolescents between the ages of 13 and 15 had consumed alcohol or tobacco, respectively, in the 30 days prior to the interview, whilst $7.3 \%$ had tried some type of illicit drug at least once in their lives 3 . Substance use in adolescence is associated with substance use in adulthood, and it is a predictor of the future burden of substancerelated diseases $1,4,5$. The consumption of alcohol, tobacco and illicit drugs has been associated with several short- and long-term health problems, such as injuries, unprotected sex, cognitive deficits, mental health problems and premature death, caused mainly by traffic accidents, homicides and suicides 5,6,7,8. Furthermore, it is related to social and economic problems for both users and society, like interpersonal violence and higher costs from medical treatment for the family and health system 6,9 .

Numerous social, economic, demographic and family-related factors are associated with substance use in adolescence 4,10. Although life experiences during childhood are not the only factors responsible for the greater risk for substance use, they can play a key role that deserves to be studied 11,12,13,14,15. The occurrence of adverse childhood experiences (ACEs) has been related to a higher risk of substance use among adolescents and adults 11,12,13,14,15,16,17. The ACEs are sources of stress that people may experience early in life, usually before the age of 18 , which include multiple types of abuse (physical, sexual, and psychological), neglect, and several sorts of family dysfunction 18,19. Many types of ACEs have been described to be associated with the beginning and continued consumption of alcohol, tobacco and illicit drugs during adolescence $2,4,11,12,13,14,15,16,17,20,21$. Some evidence for higher risk of substance use has been found for parental divorce, neglect, domestic violence, physical abuse, sexual abuse, a poor relationship or lack of communication with parents, family background of drug addiction, and unstructured families 2,4,11,12,13,14,15,16,17,20,21. The association between ACEs and substance use can differ according to gender 13,22 , and females may have a higher risk than males 13 .

However, it is known that ACEs do not occur independently, and the likelihood of having several ACEs is higher once a single ACE is reported 18,23.
Nevertheless, only a few studies, all outside of Brazil, have assessed the relationship between the occurrence of multiple types of ACEs simultaneously and substance use, showing that a higher number of adversities during childhood is related to alcohol, tobacco and illicit drugs consumption $12,15,17,18,21$. Thus, the aim of this study was to assess the association between multiple ACEs and consumption of alcohol, tobacco and illicit drugs among 15-year-old adolescents from a mediumsized city in southern Brazil.

\section{Methods}

In 1993, all children born alive in hospitals whose mothers lived in the urban area of the city of Pelotas, Rio Grande do Sul, Brazil $(\mathrm{N}=5,249)$ were interviewed. More details on the methodology applied can be found in other publications 24,25 . In the 11-year follow-up, 4,452 adolescents took part in the study (87.5\% follow-up rate), whilst 4,325 were interviewed in the 15-year follow-up (85.7\% follow-up rate) $25,4,230$ of whom answered the confidential questionnaire.

The ACEs assessed were physical abuse, sexual abuse, physical neglect, emotional neglect, and domestic violence. Physical abuse was evaluated by the question: "Has an adult from your family or someone who was looking after you hit you in a way that left you hurt or bruised?". Sexual abuse was assessed with the question: "Has anyone ever tried to do sexual things to you against your will, threatening or hurting you?". Physical neglect was assessed by "Have you ever not had enough food at home or had to wear dirty or worn clothes because you had no others?". Emotional neglect was considered as a positive response to at least one of the following questions: "Have you ever thought or felt that your parents did not want you to have been born? or "Have you ever thought or felt that someone in your family hates you?". Domestic violence was evaluated by: "Have there ever been fights with physical assault in your household between adults or has an adult ever assaulted a child or adolescent?". These data were obtained in the 15-year follow-up through a self-applied questionnaire, with the adolescents being identified only by a numeric code. The questionnaire was handed out to the adolescents, answered in a reserved place, and placed in a sealed envelope upon completion. A score was generated for the occurrence of ACEs where each affirmative answer was worth one point, varying from zero to five points. For the analyses, this score was categorized into 0, 1, 2, and 3 or more ACEs.

The outcomes assessed were: use of alcohol, tobacco and illicit drugs. The use of alcohol and 
tobacco was assessed by the following questions: "How many days did you smoke in the last 30 days?" and "How many days did you drink alcohol in the last 30 days?". If the adolescents had smoked or had drunk alcohol at least once within the prior 30 days, they were considered as user of tobacco or alcohol, respectively. The experimentation of illicit drugs was assessed by the following question: "Have you ever tried any of these?" followed by these options: shoemaker's glue, solvent or thinner, cocaine, and marijuana. These data were also obtained in the 15-year follow-up through a self-applied and confidential questionnaire. Illicit drug use was considered when the interviewee reported having used at least one of the drugs investigated.

The covariates, used as potential confounders, were collected in the perinatal and 11-year follow-up. At the perinatal visit, information on gender (male/female) and skin color (white/ non-white) was collected. At age 11 the following information was gathered: economic level, measured by the assets index, constructed based on principal components analysis of the ownership of a series of domestic goods and characteristics of the residence 24 (in quintiles); mother's schooling (0-4, 5-8, 9-11, and 12 or more years); maternal smoking (never smoked, former smoker, current smoker); maternal alcohol intake (use in the 30 days prior to the interview - yes/no); adolescent's tobacco use (use in the 30 days prior to the interview - yes/no), alcohol intake (use in the 30 days prior to the interview - yes/no), and drug experimentation (yes/no); mother's mental health, measured using the short-version of the Self-Reporting Questionnaire - SRQ-20 26; and adolescent's mental health, measured using the Strengths and Difficulties Questionnaire - SDQ 27. The cut-off point in the SRQ-20 was set at $7 / 8$ and the mothers were divided into two groups: no common mental disorder (a score less than or equal to seven) and common mental disorder (a score equal to or greater than eight) 26. For the SDQ, the adolescents' behavior was divided into three groups: normal (score 0-15), borderline (score 16-19) and abnormal (score 20-40) 27.

The analyses were performed using the software Stata 13.1 (StataCorp LP, College Station, USA). First, a descriptive analysis of the data was carried out, reporting the proportions of the independent variables and outcomes, and their respective $95 \%$ confidence intervals (95\%CI). Then a bivariate analysis was conducted using chi-squared test. For crude and adjusted analyses, Poisson regression with robust variance adjustment was used to estimate prevalence ratios (PR) and their respective 95\%CI, and a Wald test was used to test the associations. The adjusted model included all the covariates defined above. All the analyses were stratified by gender.

The study was approved by the Ethics Research Committee of the Medical School of the Federal University of Pelotas under protocol 40600026. After accepting taking part in the study, the mothers (or caretakers) and adolescents signed the term of free and informed consent.

\section{Results}

The description of the sample according to the socioeconomic, demographic, behavioral and health characteristics of the adolescents and their mothers is presented in Table 1. More than half of the adolescents were female and two thirds reported white skin color. Concerning the mothers, nearly $70 \%$ had up to eight years of schooling, $31.7 \%$ were smokers, and $45.4 \%$ reported alcohol intake. At 11 years old, $1.4 \%$ of the adolescents reported tobacco use and $6 \%$ reported alcohol use, whilst about $0.5 \%$ had ever tried some type of illicit drug. Alcohol and drug use was higher among males than among females (at the threshold of statistical significance). Regarding mental health, $30.9 \%$ of the mothers had a common mental disorder, and about $14 \%$ of the adolescents had abnormal behavior; this prevalence was higher among males than females.

Figure 1 shows the prevalence of each childhood adversity and the ACE score. The most commonly reported ACE was emotional neglect (20.2\%), followed by domestic violence $(10.4 \%)$ and physical abuse (7.1\%). All the ACEs but physical neglect were more reported by females. Nearly $30 \%$ of the adolescents had at least one ACE, and $10.2 \%$ reported two or more ACEs. Females were more likely to report a higher number of ACEs than males.

The prevalence of alcohol and tobacco use, and illicit drugs experimentation at 15 years old is presented in Figure 2. Approximately 25\% of the adolescents reported alcohol consumption, $6 \%$ reported tobacco use, and $2.1 \%$ reported illicit drugs experimentation. The prevalence of illicit drugs experimentation was similar across gender. However, alcohol and tobacco use were higher among females than males.

Table 2 shows the prevalence of substance use according to the ACE score, and the crude and adjusted prevalence ratios of the relationship between number of ACEs and consumption of alcohol, tobacco and illicit drugs, stratified by gender. After adjusting for potential confounding variables, a dose-response relation was observed between ACE score and almost all types of sub- 
Socioeconomic, demographic, behavioral and health characteristics of the participants. 1993 Pelotas (Brazil) Birth Cohort, follow-up at 11 years old.

\begin{tabular}{|c|c|c|c|c|}
\hline Variables & $\begin{array}{c}\text { Total } \\
(\mathrm{N}=4,230) \\
\mathrm{n}(\%)\end{array}$ & $\begin{array}{c}\text { Male } \\
(n=2,056) \\
\%\end{array}$ & $\begin{array}{c}\text { Female } \\
(\mathrm{n}=2,174) \\
\%\end{array}$ & p-value * \\
\hline Skin color & & & & 0.551 \\
\hline White & $2,712(66.6)$ & 67.1 & 66.2 & \\
\hline Non-white & 1,359 (33.4) & 32.9 & 33.8 & \\
\hline Assets index ** & & & & 0.484 \\
\hline 1st quintile (lowest) & 791 (19.7) & 20.4 & 18.9 & \\
\hline 2nd quintile & $794(19.7)$ & 19.4 & 20.0 & \\
\hline 3rd quintile & $816(20.2)$ & 19.4 & 21.0 & \\
\hline 4th quintile & $816(20.2)$ & 20.0 & 20.5 & \\
\hline $5^{\text {th }}$ quintile (highest) & $816(20.2)$ & 20.8 & 19.6 & \\
\hline Mother's schooling (years) & & & & 0.813 \\
\hline $0-4$ & $1,043(25.1)$ & 25.5 & 24.8 & \\
\hline $5-8$ & $1,800(43.4)$ & 42.6 & 44.1 & \\
\hline $9-11$ & $898(21.7)$ & 21.9 & 21.4 & \\
\hline 12 or more & $406(9.8)$ & 10.0 & 9.6 & \\
\hline Maternal smoking & & & & 0.523 \\
\hline Never smoked & $1,914(46.1)$ & 46.9 & 45.3 & \\
\hline Former smoker & $922(22.2)$ & 21.6 & 22.8 & \\
\hline Current smoker & $1,319(31.7)$ & 31.6 & 31.9 & \\
\hline Maternal alcohol intake *** & & & & 0.574 \\
\hline No & $2,268(54.6)$ & 55.0 & 54.2 & \\
\hline Yes & $1,888(45.4)$ & 45.0 & 45.9 & \\
\hline 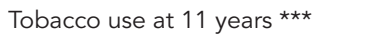 & & & & 0.373 \\
\hline No & $4,077(98.6)$ & 98.4 & 98.8 & \\
\hline Yes & $57(1.4)$ & 1.6 & 1.2 & \\
\hline Alcohol intake at 11 years *** & & & & 0.048 \\
\hline No & $3,883(94.0)$ & 93.3 & 94.7 & \\
\hline Yes & $245(6.0)$ & 6.7 & 5.3 & \\
\hline Drug experimentation at 11 years & & & & 0.045 \\
\hline No & $4,168(99.5)$ & 99.3 & 99.8 & \\
\hline Yes & $19(0.5)$ & 0.7 & 0.2 & \\
\hline Mother's mental health (SRQ-20) & & & & 0.317 \\
\hline No common mental disorders & $3,042(69.1)$ & 68.6 & 70.1 & \\
\hline Common mental disorders & $1,360(30.9)$ & 31.4 & 29.9 & \\
\hline Adolescent's mental health (SDQ) & & & & $<0.001$ \\
\hline Normal & $2,985(69.7)$ & 67.0 & 72.9 & \\
\hline Borderline & $702(16.4)$ & 17.8 & 14.8 & \\
\hline Abnormal & 598 (13.9) & 15.2 & 12.3 & \\
\hline
\end{tabular}

SDQ: Strengths and Difficulties Questionnaire; SRQ-20: Self-Reporting Questionnaire.

* Chi-squared heterogeneity test;

** Highest number of missing information: 197;

*** Use in the 30 days prior to the interview.

stance, particularly illicit drugs. A higher prevalence of alcohol, tobacco and illicit drugs use was observed among those who have had more ACEs.
The higher number of ACEs was associated with tobacco use only among females, and the risk for illicit drug experimentation differed according 
Figure 1

Prevalence of adverse childhood experiences (ACEs) among participants. 1993 Pelotas (Brazil) Birth Cohort, follow-up at 15 years old.

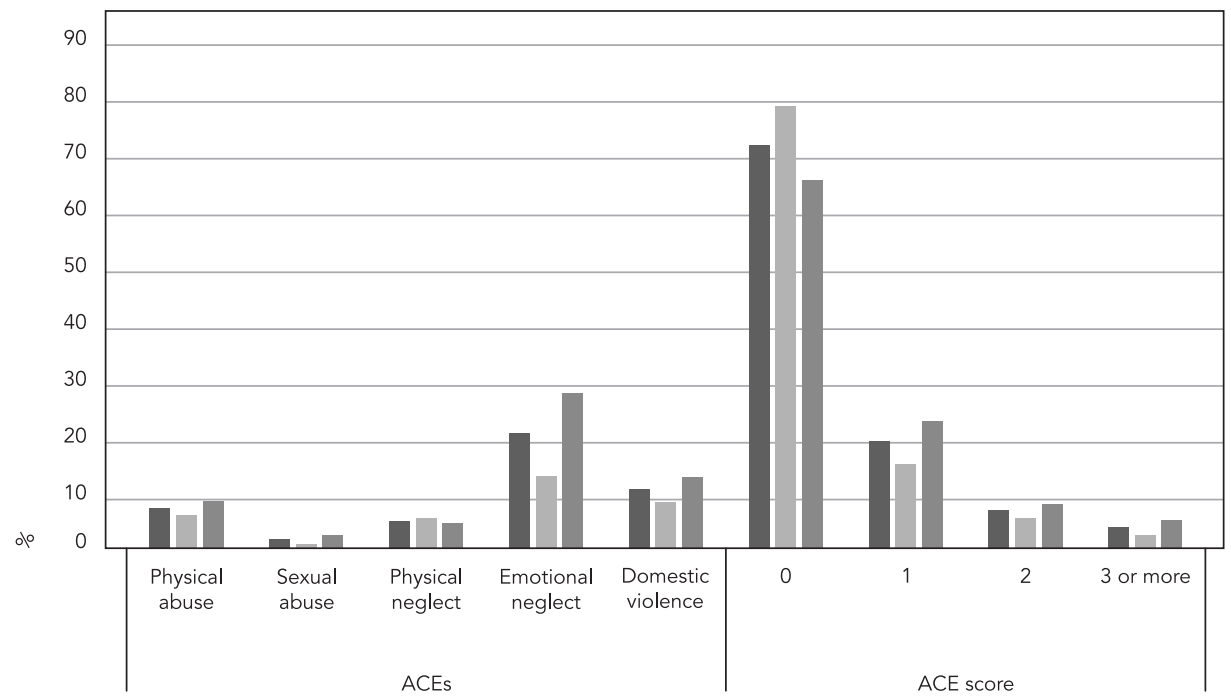

Prevalence of alcohol, tobacco, and illicit drug consumption by adolescents. 1993 Pelotas (Brazil) Birth Cohort, follow-up at 15 years old.

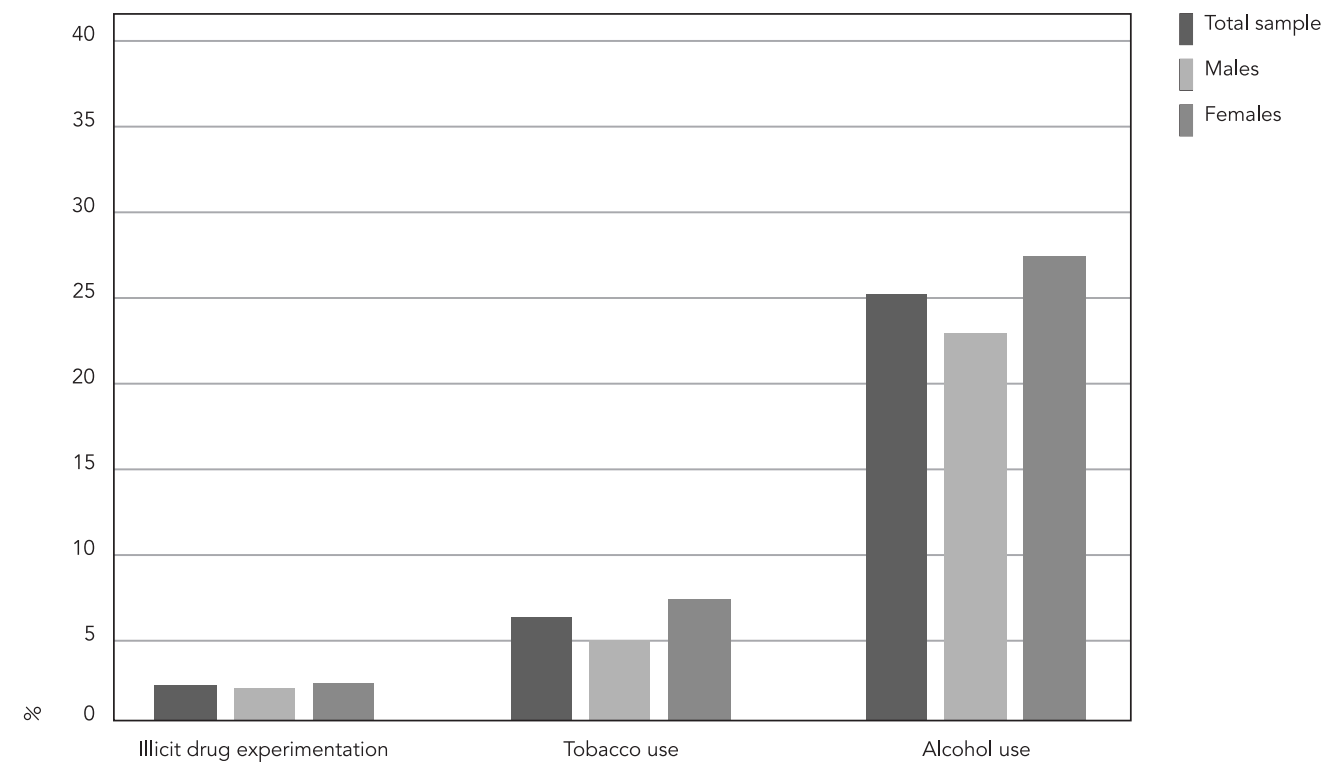


Crude and adjusted prevalence ratios for substance use according to adverse childhood experience (ACE) score, stratified by gender. 1993 Pelotas (Brazil) Birth Cohort.

\begin{tabular}{|c|c|c|c|c|c|c|}
\hline \multirow[t]{2}{*}{ ACE score } & \multicolumn{2}{|c|}{ Tobacco } & \multicolumn{2}{|c|}{ Alcohol } & \multicolumn{2}{|c|}{ Illicit drugs } \\
\hline & $\begin{array}{l}\text { Crude PR } \\
(95 \% \mathrm{Cl})\end{array}$ & $\begin{array}{l}\text { Adjusted PR * } \\
(95 \% \mathrm{Cl})\end{array}$ & $\begin{array}{l}\text { Crude PR } \\
(95 \% \mathrm{Cl})\end{array}$ & $\begin{array}{l}\text { Adjusted PR * } \\
(95 \% \mathrm{Cl})\end{array}$ & $\begin{array}{l}\text { Crude PR } \\
(95 \% \mathrm{Cl})\end{array}$ & $\begin{array}{c}\text { Adjusted PR * } \\
(95 \% \mathrm{Cl})\end{array}$ \\
\hline \multicolumn{7}{|l|}{ Males } \\
\hline 0 & 1.0 (Reference) & 1.0 (Reference) & 1.0 (Reference) & 1.0 (Reference) & 1.0 (Reference) & 1.0 (Reference) \\
\hline 1 & $2.3(1.5,3.7)$ & $2.3(1.4,3.8)$ & $1.6(1.3,2.0)$ & $1.5(1.2,1.9)$ & $2.5(1.1,5.4)$ & $3.0(1.2,7.4)$ \\
\hline 2 & $1.6(0.7,3.8)$ & $0.9(0.3,2.7)$ & $1.8(1.4,2.4)$ & $1.8(1.3,2.5)$ & $4.0(1.5,10.4)$ & $4.0(1.4,11.7)$ \\
\hline 3 or more & $2.1(0.7,6.4)$ & $2.0(0.5,8.3)$ & $1.9(1.2,2.8)$ & $2.0(1.3,3.1)$ & $4.0(1.0,16.8)$ & $5.3(1.5,19.4)$ \\
\hline \multicolumn{7}{|l|}{ Females } \\
\hline 0 & 1.0 (Reference) & 1.0 (Reference) & 1.0 (Reference) & 1.0 (Reference) & 1.0 (Reference) & 1.0 (Reference) \\
\hline 1 & $3.4(2.3,5.0)$ & $3.1(2.0,4.8)$ & $1.7(1.4,2.0)$ & $1.7(1.4,2.0)$ & $4.7(2.0,11.3)$ & $3.3(1.2,9.2)$ \\
\hline 2 & $5.5(3.5,8.5)$ & $4.5(2.7,7.3)$ & $1.8(1.4,2.2)$ & $1.8(1.4,2.3)$ & $6.5(2.3,18.5)$ & $3.7(1.0,13.0)$ \\
\hline 3 or more & $6.9(4.3,11.0)$ & $5.2(2.9,9.3)$ & $2.4(1.9,2.9)$ & $2.4(1.8,3.1)$ & $26.1(11.4,59.6)$ & $25.5(10.5,61.8)$ \\
\hline
\end{tabular}

95\% Cl: 95\% confidence interval; PR: prevalence ratio.

* Adjusted for property index, skin color, mother's schooling, mother smoking, mother's alcohol use, adolescent's use of alcohol, use of tobacco, and drug experimentation at age 11, mother's mental health, and adolescent's mental health.

to gender. Females who had three or more ACEs had a prevalence of illicit drugs experimentation almost 5 times higher than males.

\section{Discussion}

The results of this study show a positive association between multiple ACEs and alcohol, tobacco, and illicit drugs use among 15-yearold adolescents. They also show that emotional neglect, domestic violence and physical abuse were the most frequently reported ACEs, whilst alcohol and tobacco were the most consumed substances.

The prevalence of alcohol and tobacco use found in this study was similar to other broader scope Brazilian studies such as PeNSE 3. The widespread use of alcohol and tobacco may be justified since it is a socially accepted drug seen as pleasurable throughout the world, besides the constant exposition to the publicity of alcoholic drinks in Brazil 28 and the great availability and easy access to them 29. Regarding illicit drugs experimentation, a prevalence below the one observed in PeNSE ${ }^{3}$ was seen, even though similar drugs were investigated in both studies. It is worth pointing out that in the nationwide survey, despite the fact that most students were between 13 and 15 years old, older adolescents were also interviewed, which may account for the higher prevalence of drug use compared to the present study, since drug use tends to increase with age $1,30,31$.

As shown in other studies, these substances are more widely consumed by males $1,32,33$. However, researchers who assess alcohol use, taking gender differences into account, have revealed that the social pressures are related to the increase of alcohol consumption among women as a way of relieving stress or for them to match the behaviors accepted for males, particularly among those with more schooling ${ }^{34}$. Similar patterns can happen with tobacco use 35 . Although these behaviors have been found in adults 34 , they could start during adolescence, explaining the higher prevalence of alcohol and tobacco use among females. As well as alcohol and tobacco, illicit drugs also play a role in facing adversities, and its consumption has increased in recent years among Brazilian adolescents ${ }^{3}$. A differential relief assigned to illicit drugs can have great influence in its consumption 17.

Compared to those who reported no ACEs, the adolescents who experienced more adverse experiences had higher prevalence for substance use. Other studies have also shown that being exposed to several adversities during childhood, particularly different types of violence, abuse and conflict with the parents, increases the risk of substance use in adolescence and/or adulthood 11,12,14,17,18. The dose-response effect found in this and other studies can be linked to a number of factors that may explain the substance use. 
The occurrence of ACEs can contribute to the adoption of behavioral and psychological coping mechanisms, which can leverage the adoption of negative health behaviors, such as alcohol, tobacco and illicit drugs consumption 17. Being exposed to one or more ACEs may disclose to the adolescents the feeling of being poorly protected, and therefore of having a faulty family and social support 17,36. Coupled with this, is the idea and the perceived (and biologically explained) fact that substance use causes emotional relief and pleasure, even if temporary ${ }^{2}$. Furthermore, substance use among those who experienced ACEs may be mediated by psychiatric disorders, such as post-traumatic stress and depression 37 .

Few studies have assessed gender-specific associations between ACEs and substance use 13,22, and our findings suggest a higher prevalence for tobacco use and illicit drug experimentation among females who had a higher number of ACEs. Considering the idea of scarce sources of social and family support for those who were more victimized and the higher risk for illicit drugs and tobacco use, it is believed that girls can be more easily persuaded to use illicit drugs and tobacco, and also to believe that this behavior is "appropriate" and not harmful in short- and long-term 22 . However, more studies assessing the interactions between multiple ACEs and gender in the association with substance use should be encouraged.

Some limitations in this study must be highlighted. First, the possibility of information bias regarding the questionnaire used for data collection cannot be rejected. In the substance use report, particularly of illicit drugs, even the guaranteed anonymity might not have kept some adolescents from revealing use, whether due to self-censorship, memory failure, guilt, or for being linked to the study, whose regular follow-ups might allow them to be identified. In this context, drugs use prevalence may be interpreted as minimum estimates of the actual values, which might be higher than those found. Nevertheless, the use of a self-applied confidential questionnaire guarantees anonymity and is one of the procedures to obtain information on this type of behavior 38. Secondly, in spite of knowing that the importance attributed to each adversity can interfere on how the event is perceived, as well as its reactions, the way in which the ACE affected the adolescent could not be ascertained. Moreover, despite being a cohort study, both exposures and outcomes were investigated at the same time, and the timing of the ACE occurrence was not assessed; this could lead to reverse causality. However, studies suggest that adverse experiences are more likely to happen in young infancy or soon after the onset of puberty ${ }^{39}$. Although it was not possible to determine the temporal relationship of the association between ACEs and substance use in this study, it does not mean the results have no relevance, since both ACEs and use of substance in adolescence can be harmful to health in later life, and interrupting this chain could be beneficial to the individual's health over time. The lack of information on other possible confounding factors (e.g. parent-child relationship, problems at school, and other family environment characteristics) is also a limitation. However, it was possible to adjust for several confounders usually assessed in the literature and collected prospectively.

It is also pointed out that this study was carried out on a representative sample of the adolescents born in the city of Pelotas, with a high follow-up rate of over $85 \% 25$, which made it possible to assess the association between the occurrence of multiple ACEs and substance use with adjustment for important potential confounding factors such as socioeconomic characteristics, and the mental health of the adolescents and their mothers.

In conclusion, the results showed that a higher number of ACEs are related to alcohol, tobacco and illicit drug use during adolescence, and this relation can differ according to gender for some substances. These findings indicate that the strategies for preventing substance use must feature interventions both among adolescents and within the family environment. Adverse childhood experiences should be investigated, tracked and seen as a not just a familiar or individual problem, but also of social interest. 


\section{Contributors}

H. Gonçalves designed the study and reviewed the final version of the manuscript. A. L. G. Soares conducted the statistical analyses, wrote the first draft of the manuscript, and reviewed the final version of the manuscript. A. P. G. Santos and C. G. Ribeiro conducted literature searches and provided summaries of previous research studies about the theme, conducted the statistical analyses and wrote the first draft of the manuscript. I. O. Bierhals, L. S. Vieira and N. L. Hellwig conducted literature searches and provided summaries of previous research studies about the theme, also wrote the first draft of the manuscript. F. C. Wehrmeister and A. M. B. Menezes designed the study and reviewed the final version of the manuscript. All authors contributed to and have approved the final manuscript.

\section{References}

1. Barbosa Filho VC, Campos W, Lopes AS. Prevalence of alcohol and tobacco use among Brazilian adolescents: a systematic review. Rev Saúde Pública 2012; 46:901-17.

2. Malbergier A, Cardoso LRD, Amaral RA. Uso de substâncias na adolescência e problemas familiares. Cad Saúde Pública 2012; 28:678-88.

3. Instituto Brasileiro de Geografia e Estatística. Pesquisa Nacional de Saúde do Escolar (PeNSE), 2012. Rio de Janeiro: Instituto Brasileiro de Geografia e Estatística; 2012.

4. Sitnick SL, Shaw DS, Hyde LW. Precursors of adolescent substance use from early childhood and early adolescence: testing a developmental cascade model. Dev Psychopathol 2014; 26:125-40.

5. Lopes GM, Nobrega BA, Del Prette G, Scivoletto S. Use of psychoactive substances by adolescents: current panorama. Rev Bras Psiquiatr 2013; 35 Suppl 1:S51-61.

6. Burke PJ, O'Sullivan J, Vaughan BL. Adolescent substance use: brief interventions by emergency care providers. Pediatr Emerg Care 2005; 21:770-6.

7. Marshall EJ. Adolescent alcohol use: risks and consequences. Alcohol Alcohol 2014; 49:160-4.

8. McCambridge J, McAlaney J, Rowe R. Adult consequences of late adolescent alcohol consumption: a systematic review of cohort studies. PLoS Med 2011; 8:e1000413.

9. Sindelar HA, Barnett NP, Spirito A. Adolescent alcohol use and injury: a summary and critical review of the literature. Minerva Pediatr 2004; 56:291-309.

\section{Acknowledgments}

This article is based on data from the Pelotas Birth Cohort, 1993, conducted by the Postgraduate Program in Epidemiology at the Federal University of Pelotas with the collaboration of the Brazilian Public Health Association (ABRASCO). From 2004, the Wellcome Trust supported the 1993 birth cohort study. The European Union, National Support Program for Centers of Excellence (PRONEX), the Brazilian National Research Council (CNPq), and the Brazilian Ministry of Health supported previous phases of the study.
10. Kliewer W, Murrelle L. Risk and protective factors for adolescent substance use: findings from a study in selected Central American countries. J Adolesc Health 2007; 40:448-55.

11. Afifi TO, Henriksen CA, Asmundson GJ, Sareen J. Childhood maltreatment and substance use disorders among men and women in a nationally representative sample. Can J Psychiatry 2012; 57:677-86.

12. Dube SR, Miller JW, Brown DW, Giles WH, Felitti VJ, Dong M, et al. Adverse childhood experiences and the association with ever using alcohol and initiating alcohol use during adolescence. J Adolesc Health 2006; 38:444.e1-10.

13. Fuller-Thomson E, Filippelli J, Lue-Crisostomo CA. Gender-specific association between childhood adversities and smoking in adulthood: findings from a population-based study. Public Health 2013; 127:449-60.

14. Madruga CS, Laranjeira R, Caetano R, Ribeiro W, Zaleski M, Pinsky I, et al. Early life exposure to violence and substance misuse in adulthood - the first Brazilian national survey. Addict Behav 2011; 36:251-5.

15. Ford ES, Anda RF, Edwards VJ, Perry GS, Zhao G, Li $\mathrm{C}$, et al. Adverse childhood experiences and smoking status in five states. Prev Med 2011; 53:188-93.

16. Bernardy CCF, Oliveira MLF. O papel das relações familiares na iniciação ao uso de drogas de abuso por jovens institucionalizados. Rev Esc Enferm USP $2010 ; 44: 11-7$. 
17. Wright EM, Fagan AA, Pinchevsky GM. The effects of exposure to violence and victimization across life domains on adolescent substance use. Child Abuse Negl 2013; 37:899-909.

18. Felitti VJ, Anda RF, Nordenberg D, Williamson DF, Spitz AM, Edwards V, et al. Relationship of childhood abuse and household dysfunction to many of the leading causes of death in adults. The Adverse Childhood Experiences (ACE) Study. Am J Prev Med 1998; 14:245-58.

19. World Health Organization. Adverse Childhood Experiences International Questionnaire (ACE-IQ). http://www.who.int/violence_injury_prevention/ violence/activities/adverse_childhood_experienc es/en/ (accessed on 27/Jul/2015).

20. Madruga CS, Laranjeira R, Caetano R, Pinsky I, Zaleski M, Ferri CP. Use of licit and illicit substances among adolescents in Brazil: a national survey. Addict Behav 2012; 37:1171-5.

21. Schwandt ML, Heilig M, Hommer DW, George DT, Ramchandani VA. Childhood trauma exposure and alcohol dependence severity in adulthood: mediation by emotional abuse severity and neuroticism. Alcohol Clin Exp Res 2013; 37:984-92.

22. Mersky JP, Topitzes J, Reynolds AJ. Impacts of adverse childhood experiences on health, mental health, and substance use in early adulthood: a cohort study of an urban, minority sample in the U.S. Child Abuse Negl 2013; 37:917-25.

23. Dong M, Anda RF, Felitti VJ, Dube SR, Williamson DF, Thompson TJ, et al. The interrelatedness of multiple forms of childhood abuse, neglect, and household dysfunction. Child Abuse Negl 2004; 28:771-84.

24. Araújo CL, Menezes AMB, Vieira MFA, Neutzling MB, Gonçalves H, Anselmi L, et al. The 11-year follow-up of the 1993 Pelotas (Brazil) birth cohort study: methods. Cad Saúde Pública 2010; 26: 1875-86.

25. Gonçalves H, Assunção MCF, Wehrmeister FC, Oliveira IO, Barros FC, Victora CG, et al. Cohort profile update: the 1993 Pelotas (Brazil) birth cohort follow-up visits in adolescence. Int J Epidemiol 2014; 43:1082-8.

26. Mari JJ, Williams P. A validity study of a psychiatric screening questionnaire (SRQ-20) in primary care in the city of Sao Paulo. Br J Psychiatry 1986; 148:23-6.

27. Fleitlich B, Cortázar PG, Goodman R. Questionário de capacidades e dificuldades (SDQ). Infanto Rev Neuropsiquiatr Infanc Adolesc 2000; 8:44-50.
28. Pinsky I, El Jundi SA. O impacto da publicidade de bebidas alcoólicas sobre o consumo entre jovens: revisão da literatura internacional. Rev Bras Psiquiatr 2008; 30:362-74.

29. Vieira DL, Ribeiro M, Romano M, Laranjeira RR. Álcool e adolescentes: estudo para implementar políticas municipais. Rev Saúde Pública 2007; 41:396-403.

30. Horta RL, Horta BL, Costa AWN, Prado RR, Oliveira-Campos M, Malta DC. Lifetime use of illicit drugs and associated factors among Brazilian schoolchildren, National Adolescent School-based Health Survey (PeNSE 2012). Rev Bras Epidemiol 2014; 17 Suppl 1:31-45.

31. Barreto SM, Giatti L, Casado L, Moura L, Crespo C, Malta D. Contextual factors associated with smoking among Brazilian adolescents. J Epidemiol Community Health 2012; 66:723-9.

32. Malta DC, Machado IE, Porto DL, Silva MMA, Freitas PC, Costa AWN, et al. Alcohol consumption among Brazilian Adolescents according to the National Adolescent School-based Health Survey (PeNSE 2012). Rev Bras Epidemiol 2014; 17 Suppl 1:203-14.

33. Moura EC, Malta DC. Alcoholic beverage consumption among adults: sociodemographic characteristics and trends. Rev Bras Epidemiol 2011; 14 Suppl 1:61-70.

34. Silveira CM, Siu ER, Wang YP, Viana MC, Andrade AG, Andrade LH. Gender differences in drinking patterns and alcohol-related problems in a community sample in Sao Paulo, Brazil. Clinics 2012; 67:205-12.

35. Glynn T, Seffrin JR, Brawley OW, Grey N, Ross H. The globalization of tobacco use: 21 challenges for the 21st century. CA Cancer J Clin 2010; 60:50-61.

36. Holt S, Buckley H, Whelan S. The impact of exposure to domestic violence on children and young people: a review of the literature. Child Abuse Negl 2008; 32:797-810.

37. Dunn MG, Tarter RE, Mezzich AC, Vanyukov M, Kirisci L, Kirillova G. Origins and consequences of child neglect in substance abuse families. Clin Psychol Rev 2002; 22:1063-90.

38. Tavares BF, Béria JU, Lima MS. Fatores associados ao uso de drogas entre adolescentes escolares. Rev Saúde Pública 2004; 38:787-96.

39. Krug EG, Dahlberg L, Mercy JA, Zwi A, Lozano R. World report on violence and health. Geneva: World Health Organization; 2002. 


\section{Resumo}

O objetivo deste estudo foi investigar a associação entre experiências adversas na infância (ACEs) e uso de álcool, fumo e drogas ilícitas em adolescentes de uma coorte brasileira. A ocorrência de cinco ACEs, o uso de álcool e fumo e a experimentação de drogas ilícitas foram investigados na Coorte de Nascimentos de 1993 de Pelotas, aos 15 anos $(n=4.230)$. Um escore de ACEs foi criado e sua associação com o uso de substâncias foi avaliada. Cerca de $25 \%$ dos adolescentes consumiram álcool, 6\% fumaram e 2,1\% relataram ter usado drogas pelo menos uma vez na vida. Os ACEs estiveram associados com o uso de álcool, fumo e drogas ilícitas. Uma relação dose-resposta entre o número de ACEs e o consumo de substâncias foi evidenciada, especialmente para drogas ilícitas. A ocorrência de ACEs esteve positivamente associada com o uso de álcool, tabaco e drogas ilícitas em adolescentes, e o risco pode diferir conforme o sexo. Esses resultados salientam que as estratégias para a prevenção do uso de substâncias devem conter intervenções para adolescentes, bem como no ambiente familiar.

Transtornos Relacionados ao Uso de Substâncias; Hábito de Fumar; Consumo de Bebidas Alcoólicas; Drogas Ilícitas; Adolescente

\section{Resumen}

El objetivo fue investigar la asociación entre experiencias adversas en la infancia (ACEs) y consumo de alcohol, tabaco y drogas ilícitas en adolescentes de una cohorte brasileña. La ocurrencia de cinco ACEs, el consumo de alcohol y tabaco y el primer consumo de drogas ilícitas se investigaron en la Cohorte de Nacimientos de 1993 de Pelotas, a los 15 años $(n=4.230)$. Se creó un marcador de ACEs y se evaluó su asociación con el uso de estas sustancias. Cerca de un 25\% de los adolescentes consumieron alcohol, un 6\% fumaron y un 2,1\% informaron haber consumido drogas por lo menos una vez en la vida. Los ACEs estuvieron asociados con el consumo de alcohol, tabaco y drogas ilícitas. Se evidenció una relación dosis-respuesta entre el número de ACEs y el consumo de sustancias, especialmente, en el caso de drogas ilícitas. La ocurrencia de ACEs estuvo positivamente asociada con el uso de alcohol, tabaco y drogas ilícitas en adolescentes y el riesgo puede diferir según sexo. Esos resultados resaltan que las estrategias para la prevención del consumo de estas sustancias deben contar con intervenciones para adolescentes, as $\hat{i}$ como en su ambiente familiar.

Trastornos Relacionados con Sustancias; Hábito de Fumar; Consumo de Bebidas Alcohólicas; Drogas Ilícitas; Adolescente
Submitted on $01 /$ Jun/2015

Final version resubmitted on 08/Oct/2015 Approved on 06/Nov/2015 